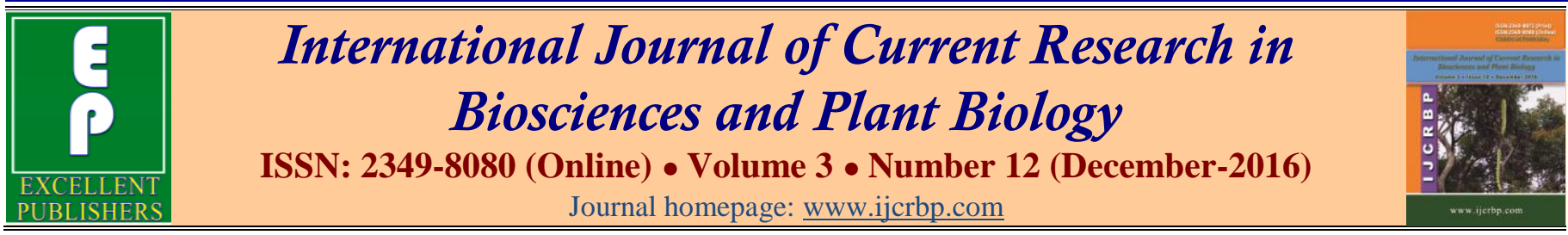

\title{
Heavy Metal Concentrations in Some Common Medicinal Plants from Different Geographical Locations in Douala, Cameroon
}

\author{
Maffo Maffo Nicole Liliane',2*, Zapfack Louis', Youmbi Emmanuel², Dibong Siegfried \\ Didier3, Ntsomboh-Ntsefong Godswill ${ }^{2,4}$ and Nanfack Arsel D'Estaing'
}

\begin{abstract}
1 Department of Plant Biology. Laboratory of Botany \& Ecology: Research Unit: Ecology/Systematics and Assessment of Carbon Stocks. Faculty of Science, P. O. Box: 812, University of Yaounde I, Cameroon

${ }^{2}$ Department of Plant Biology. Laboratory of Biotechnology \& Environment. Faculty of Science, P. O. Box: 812, University of Yaounde I, Cameroon

3Laboratory of Plant Ecology, Department of Plant Organisms and Physiology, Faculty of Science, P. O. Box 24157, University of Douala, Cameroon

4Institute of Agricultural Research for Development, CEREPAH Dibamba, P. O. Box 243 Douala, Cameroon
\end{abstract}

*Corresponding author.

\section{Abstract}

This study was aimed at investigating and comparing the levels of five heavy metals; $\mathrm{Pb}, \mathrm{Cd}, \mathrm{Cr}, \mathrm{Zn}$, and $\mathrm{Cu}$ in both leaves, shoot and root samples of six common medicinal plants: Aloe vera, Ageratum conyzoides, Cleome ciliata, Cymbopogon citratus, Eremomastax speciosa, and Justicia secunda collected from refuse dumps, roadsides and residential areas in Douala. The plant samples collected were divided into different parts. Concentrations of heavy metals were determined using Atomic Absorption Spectrometry. Results revealed that the selected medicinal plants accumulate heavy metals at different concentrations. Heavy metals repartition decreased in the trend roots $>$ shoots $>$ leaves. There was a significant difference $(p<0.0001)$ in the content of metals between plants from different collection points. Samples collected from refuse dumps showed significantly higher concentrations $(p<0.0001)$ of heavy metals followed by roadsides, then residential areas. Comparison of results with defined permissible limits led to the conclusion that the levels of all five heavy metals were beyond the permissible limits in the majority of medicinal plants analyzed. Only Ageratum conyzoides was below the permissible limit for $\mathrm{Cu}$. High heavy metal concentrations in plants indicate high level of contamination and this raises consumers' health risk concerns.
\end{abstract}

\section{Article Info}

Accepted: 15 November 2016

Available Online: 06 December 2016

Keywords

Atomic absorption spectrometry

Heavy metals

Medicinal plants

Health risk

\section{Introduction}

Medicinal plants (MP) have been playing a key role in world health for ages. People around the globe use MP in relation to their culture and historical behaviors (Rates, 2001; WHO, 2005). Though distributed worldwide, MP are most abundant in tropical countries. Approximately,
25000 plant-based formulations are available in the indigenous medical texts (Gupta et al., 2004). Nowadays, many African countries are concerned by the overwhelming urbanization, ever-growing population and pollution due to high industrialization, dense traffic, largescale agriculture, etc. The primary sources of this pollution are the burning of fossil fuels, mining and 
smelting of metallic ferrous ores, municipal wastes, fertilizers, pesticides, and sewage. Consequently, with various pollutants gradually increasing, soil and plant contamination are becoming a serious concern with typical and significant causes being anthropogenic activities (agricultural, chemical and industrial), vehicle emissions, and improper waste disposal (Krishna and Govil, 2007). Among these toxic elements, presence of heavy metals which constitute an important group of hazardous substances, are ubiquitous in nature and cause serious harmful effects on living organisms (Nies, 1999; Lee and Lee, 2002). Medicinal herbs are easily contaminated during growth, development and processing. After collection and transformation into dosage form, the heavy metals confined in plants finally enter the human body and may disturb the normal functions of vital organs. Main heavy metals like cadmium $(\mathrm{Cd})$, lead $(\mathrm{Pb})$, mercury $(\mathrm{Hg})$, arsenic (As) and chromium $(\mathrm{Cr})$ have been reported to be more toxic to plants than the others and have no other reported biological functions to plants (Fauziah et al., 2010; Ji et al., 2012).

Nonetheless, some heavy metals like copper $(\mathrm{Cu})$, zinc $(\mathrm{Zn})$ and magnesium $(\mathrm{Mg})$ are essential and required by the human body in trace amounts. When these metals exceed the acceptable limits in the body, they become toxic (at very low concentrations) and cause serious harmful effects on living organisms (Nies, 1999; Lee and Lee, 2002; Adepoju-Bello et al., 2014). They may cause damage to vital organs of the body like the central nervous system, liver, heart, kidney and brain, leading to hypertension, abdominal pain, skin eruptions, intestinal ulcer and different types of cancers (Uddin et al., 2012; Fernández-Luqueño et al., 2013).

The concentration of heavy metals in medicinal plants beyond permissible limits is an issue of great concern to public safety all over the world (Calixto, 2000). The problem is rather more serious in Cameroon, because medicinal plants which form the raw materials for the finished products are neither controlled nor properly regulated by quality assurance parameters. WHO recommends that medicinal plants which form the raw materials for the finished products should be checked for the presence of heavy metals. The WHO further regulates maximum permissible limits of toxic metals like arsenic, cadmium and lead at 1.0, 0.3 and $10 \mathrm{ppm}$, respectively (WHO, 1989 and 1998).

Due to poverty and limited access to modern medicine, many people and traditional healers of large cities in particular harvest plants for healing in nature (regardless of location) without considering their quality and sustainable management of this heritage. Besides, this is an issue reflected by the proliferation of traditional healers in search of patients in urban centers. Therefore, the raw materials that go into making their recipe are unreliable because of a polluted and corrupt environment of the cities and their outskirts. This poses a public health problem in African cities since the majority of people remain bound to traditional medicine because of its easy access and their culture, accentuated by poverty. These medicinal plants are valuable resources for health care. Even though many studies have been carried out across the world (Abou-Arab and Abou Donia, 2000; Haider et al., 2004; Shad Ali Khan et al., 2008; Ayari et al., 2010; Maharia et al., 2012; Kulhari et al., 2013; Tshibangu et al., 2014; Nawaba et al., 2015; Lion et al., 2016), data on the accumulation of heavy metals in medicinal plants harvested in the wild in Cameroon are very rare. There is increasing interest in the study of the distribution of heavy metals in medicinal plants, not because these plants are an alternative but because this accumulation constitutes a health risk for the population. Moreover, it has been reported that traditional knowledge of plants is being implemented and followed by the inhabitants of different areas of Douala (Mpondo et al., 2012; Dibong et al., 2012). Our study aims to deepen the knowledge of plants used for medicinal purposes in the Douala region of Cameroon which is densely populated, urbanized, industrialized and polluted). This city, the economic capital of Cameroon, has experienced rapid urbanization and industrialization in recent years with associated soil and air pollution enhancing pollutant accumulation in medicinal plants, thereby increasing potential human health risks.

This study was designed to determine the concentration of five heavy metals $(\mathrm{Cr}, \mathrm{Pb}, \mathrm{Cd}, \mathrm{Zn}, \mathrm{Cu})$ in leaves, shoots and root samples of six common medicinal plants (Cleome ciliata, Schum., Ageratum conyzoides Linn., Aloe vera Linn., Cymbopogon citratus Stapf., Eremomastax speciosa (Hochst.) Cufod. and Justicia secunda Vahl.) used in the treatment, prevention, and management of diseases. Samples were collected from specified locations in Douala and their contamination status was evaluated with respect to established safe limits of the WHO, China and Canadian standard guidelines (WHO, 1998). This study may help understand the importance of location and ultimately heavy metal toxicity of medicinal plants. General description of medicinal plants undertaken in the present study are given in Table 1. 
Table 1. Some medicinal plants commonly used in Douala.

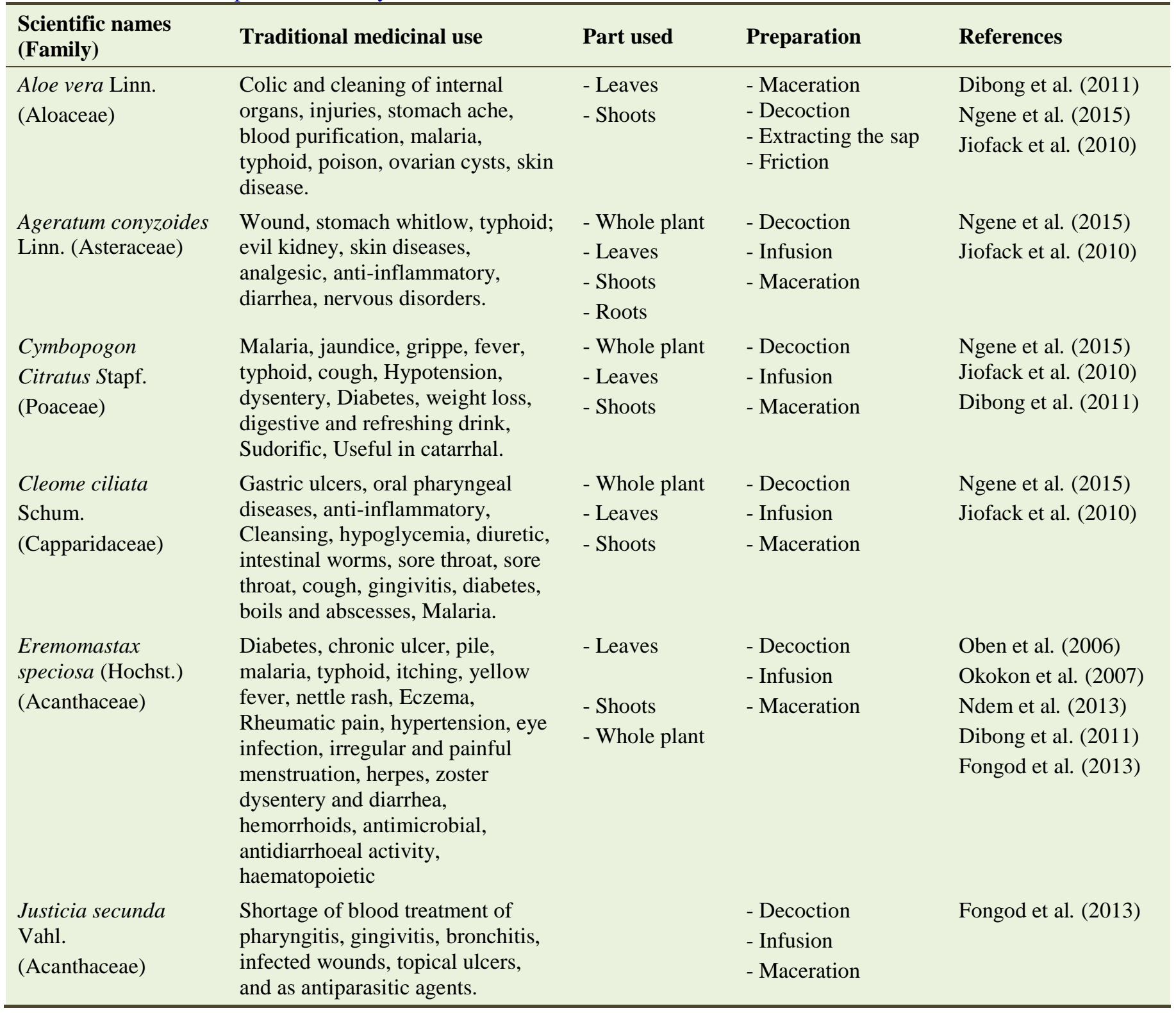

\section{Materials and methods}

\section{Description of study sites}

This study was conducted from December 2015 to February 2016 in some localities in Douala, Cameroon (Fig. 1) selected on the basis of their higher number of traditional healers, plant diversity of the region and the ancestral tradition related to traditional plant usage (Dibong et al., 2012; Priso et al., 2001). Three collection localities [residential areas (RA), roadsides (RS) and refuse dumps (RD)] were selected on the basis of survey results obtained from traditional practitioners and people concerned, presence of contaminated soil and atmospheric polluting units (presence of industries, heavy traffic and sites located near waste heaps) (Fig. 1).

The six aforementioned medicinal plant species were selected due to their significant importance in the Littoral region and their frequent utilization in novel pharmaceutical preparations, traditional drug formulations in the region, food supplements and their diverse medicinal properties. These plants which are common in most communities were selected because they are found in most herbal remedies on the Cameroonian markets and are widely used by individuals and families. 

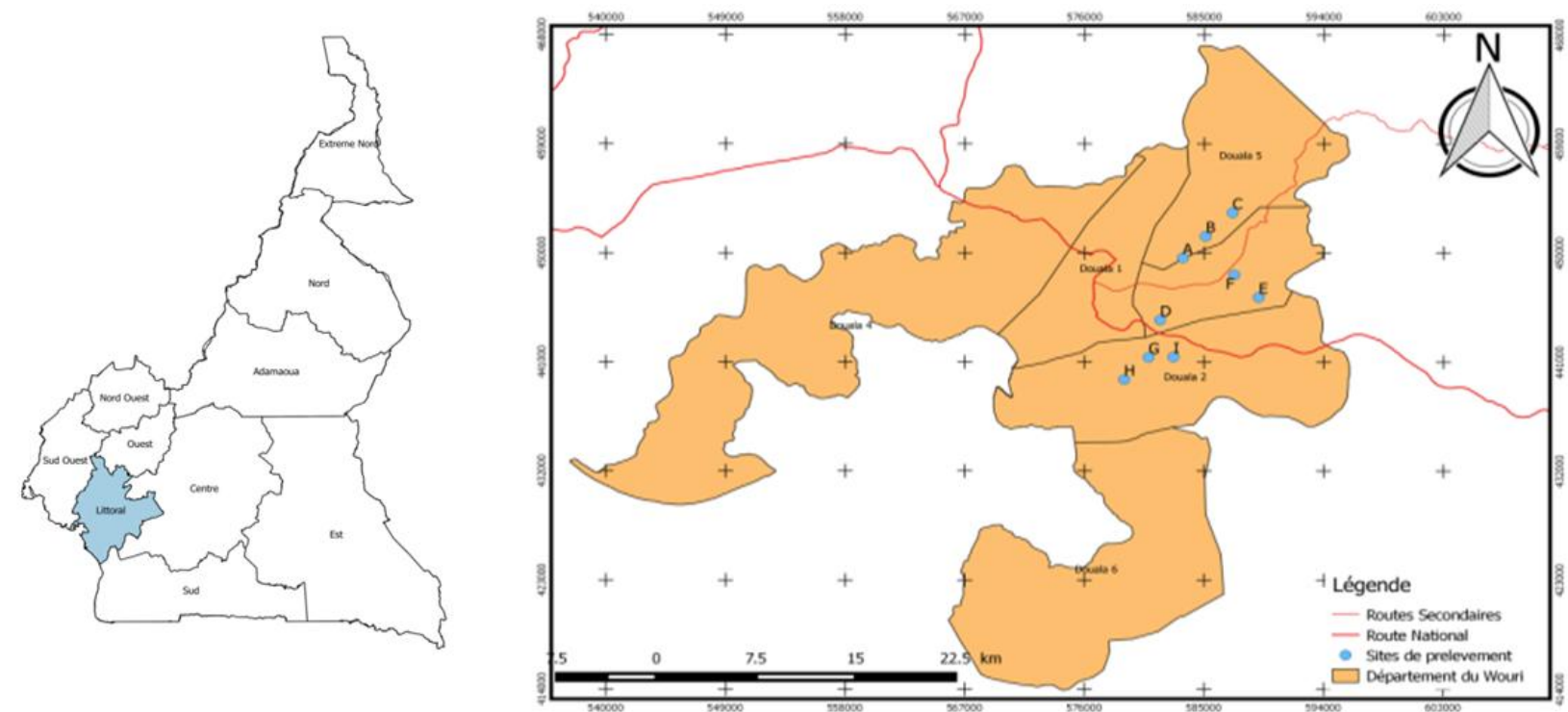

Fig. 1: Heavy metals' contents $(\mathrm{mg} / \mathrm{kg})$ in the medicinal plant samples from different geographical locations in Douala.

Douala is the largest metropolis of the coast of Cameroon with a climate that belongs to the equatorial area of a particular type called "Cameronian" characterized by two seasons. There is a long and stable rainy season with at least 9 months of heavy precipitation (about $4000 \mathrm{~mm}$ per year) and high temperatures $\left(26.7^{\circ} \mathrm{C}\right)$. The minimum average temperature in Douala for 30 years (1961-1990) was $22.6^{\circ} \mathrm{C}$ in July and the average maximum temperature was $32.3^{\circ} \mathrm{C}$ in February. The relative humidity remains high and close to $100 \%$ all year round (Dibong et al., 2012; Mpondo et al., 2012). The population of the city is estimated at 2.5 million. The intensification of urban, industrial and agricultural activities, accelerated population growth have led to increased degradation of ecosystems in that locality (Priso et al., 2011).

\section{Reagents and equipment}

Analytical grade chemicals purchased from Hach Company and doubly de-ionized distilled water were used throughout the study. 65\% nitric acid $\left(\mathrm{HNO}_{3}\right), 30 \%$ hydrogen peroxide $\left(\mathrm{H}_{2} \mathrm{O}_{2}\right)$, and $70 \%$ perchloric acid $\left(\mathrm{HClO}_{4}\right)$ were used for digestion purpose, while multielement standard solution was used as a reference.

The Digester for Heavy Metal SH 230N was used to mineralize all samples and the spectrophotometer $\mathrm{HACH}$ DR 3900 was used for analyzing the aforementioned heavy metals in the laboratory of Biotechnology and environment of the University of Yaounde I. All glassware were soaked for $48 \mathrm{~h}$ in $10 \% \mathrm{HNO}_{3}$ and all the containers were rinsed repeatedly and successively in $\mathrm{HNO}_{3} / \mathrm{H}_{2} \mathrm{O}$ (1:1) and $\mathrm{HCl} / \mathrm{H}_{2} \mathrm{O}$ (1:1) before use. All apparatus were thoroughly washed with detergent solution followed by tap water and rinsed with, distilled water (Rashid et al., 2016).

\section{Collection of samples}

The selected medicinal plant samples were randomly collected in transects of $25 \mathrm{~m}^{2}(5 \mathrm{~m} \times 5 \mathrm{~m})$, from three different sampling points (RA, RS and RD) in Douala. At each sampling site (Fig. 1), two samples of each plant were collected from six different points and mixed together. All the sample sites were far away (approximately 500-1000 m) from industrial pollution sources (such as landfill regions, gas stations and factories) and line pollution sources (about 200 meters away from houses and roads). All sites were located with GPS so as to facilitate any further investigations. Cleome ciliata Schum. (Fig. 4) and Ageratum conyzoides Linn. (Fig. 2) were harvested along RS; Aloe vera Linn. (Fig. 3) and Cymbopogon citratus Stapf. (Fig. 5) around RA; Eremomastax speciosa (Hochst.) Cufod. (Fig. 6) and Justicia secunda Vahl. (Fig. 7) in RD.

\section{Preparations of samples}

Whole plants collected from different locations were divided into different edible parts: roots, shoots, leaves. These plants parts were washed thoroughly with running tap water followed by washing with deionized autoclaved water to remove the dirt, dust particles, possible parasites. They were further rinsed again with deionized autoclaved water (Abou-Arab and Abou Donia, 2000). The plant samples were shade dried at 
$180^{\circ} \mathrm{C}$ in an auto-clave, crushed, powdered and homogenized using a laboratory blender. The powdered samples were put in plastic bags, stored in closed air

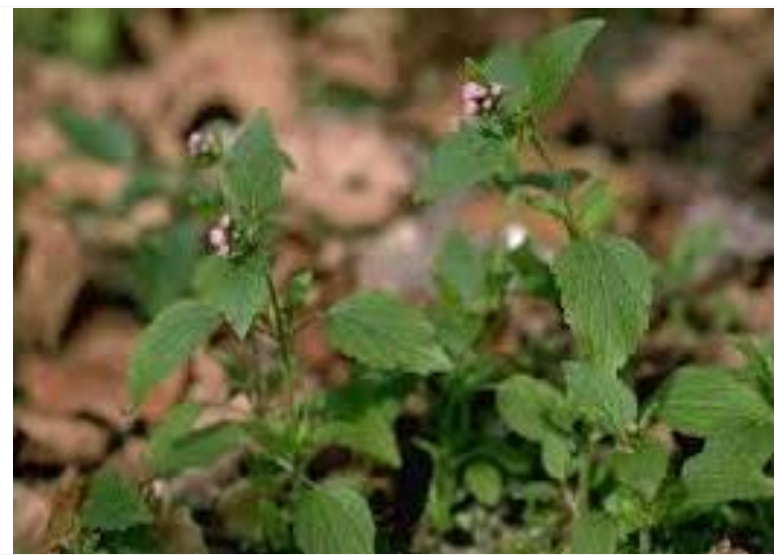

Fig. 2: Ageratum conyzoides L. (Asteraceae) Local name: Ewuda nyo na nyo

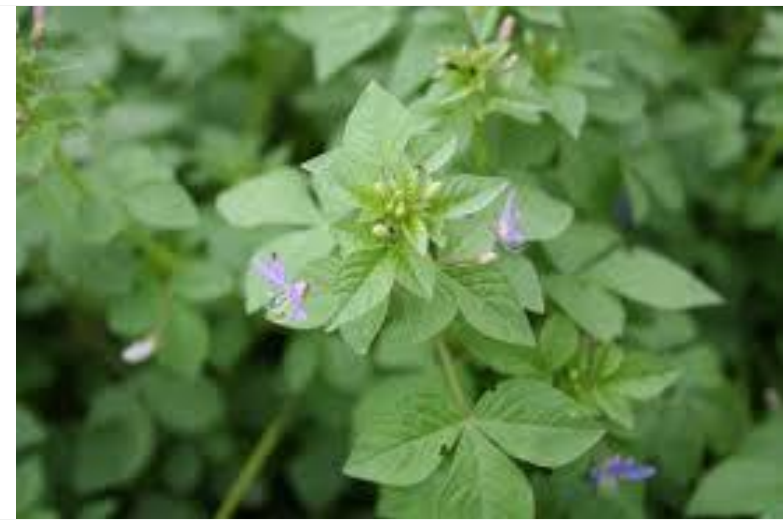

Fig. 4: Cleome ciliata L. (Capparidaceae)

Local name: Mbango

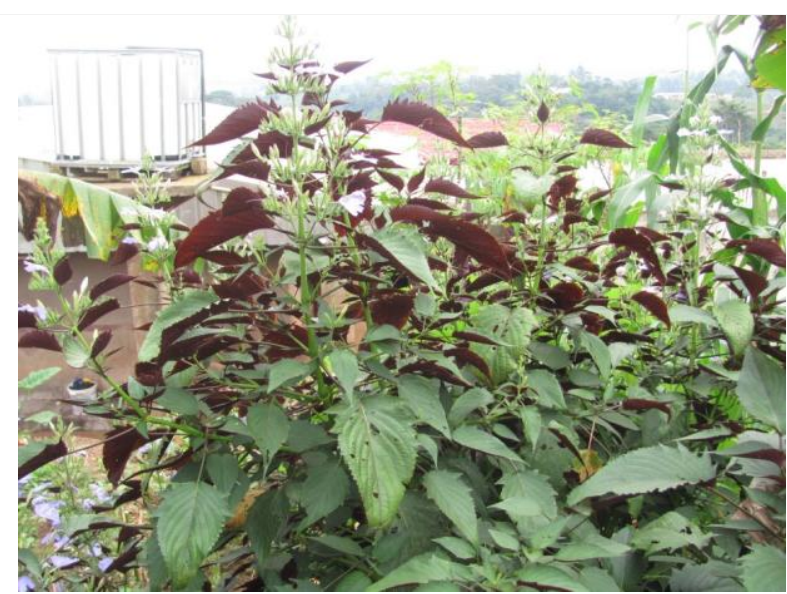

Fig. 6: Eremomastax speciosa (Hochst.) Cufod (Acanthaceae)

Local name: Dibokuboku di mole tight bottles and transported to the laboratory of Biotechnology and Environment of the University of Yaounde I for further analysis.

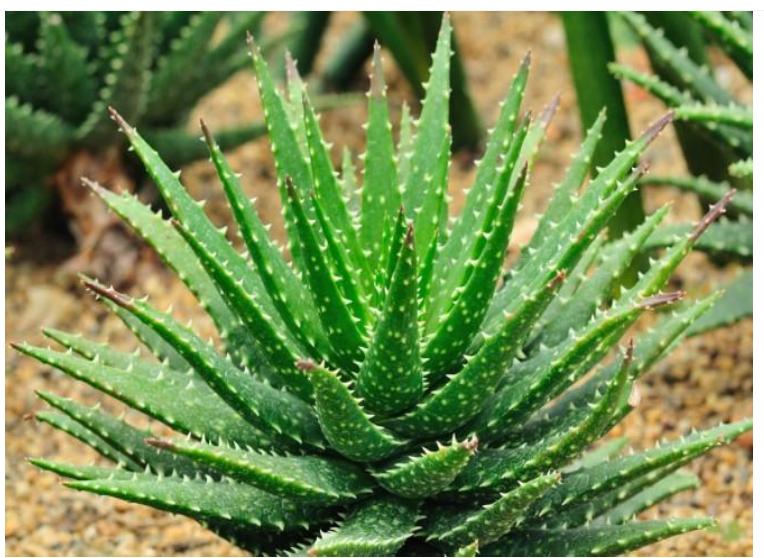

Fig.3: Aloe vera L. (Aloaceae)

Local name: Aloe vera

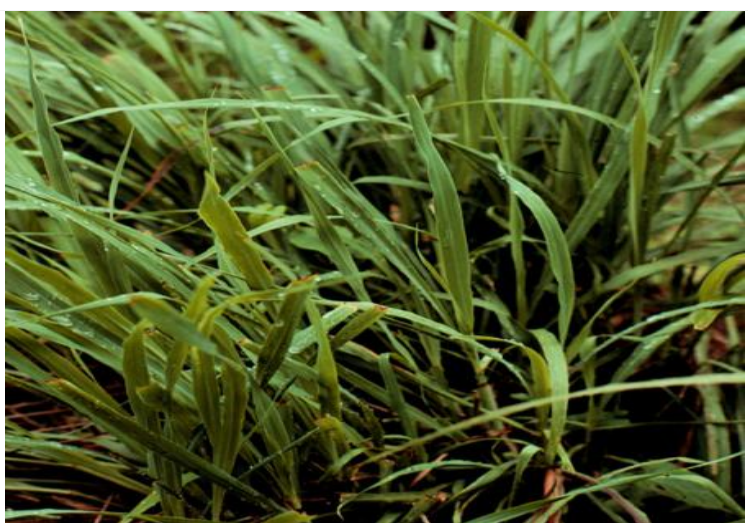

Fig. 5: Cymbopogon citratus Stapf (Poaceae)

Local name: Bekoko ba ti (citronnelle, fever grass)

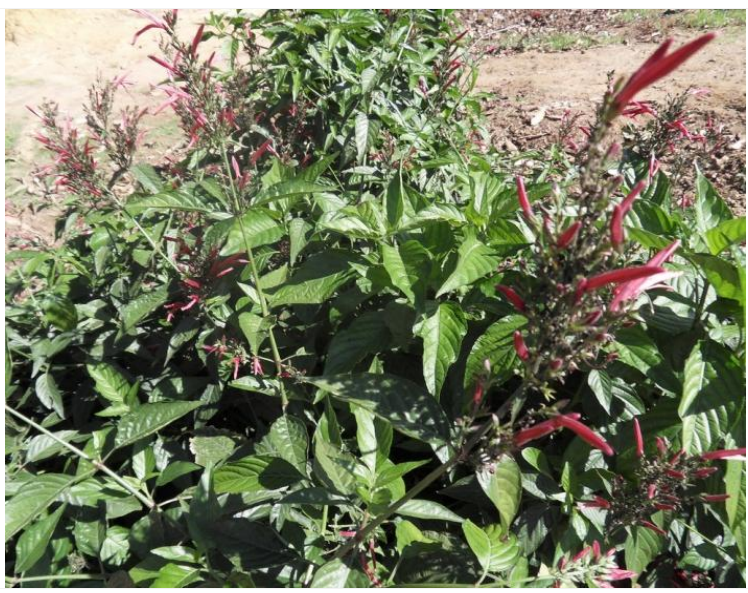

Fig. 7: Justicia secunda Vahl. (Acanthaceae)

N. L. Maffo Maffo et al. (2016) / Heavy Metal Concentrations in Some Common Medicinal Plants from Different Geographical Locations in Douala, Cameroon 


\section{Sample digestions using wet digestion procedure $\left(\mathrm{HNO}_{3}-\mathrm{HClO}_{4}\right.$ digestion)}

For heavy metals assessment, the digestion was carried out according to the methods reported by Hseu (2004) and Rashid et al. (2016). Pre-weighed $1 \mathrm{~g}$ each of different parts of each plant were placed into borosilicate digester tubes and $10 \mathrm{ml}$ of concentrated $\mathrm{HNO}_{3}$ were added in each tube. The mixture was placed on a hot plate (heavy metal digester SH 230N) for 30-45 min to allow for oxidation. After cooling, 5 $\mathrm{ml}$ of $\mathrm{HClO}_{4}(70 \%)$ was added, and the mixture was reheated on a hot plate until the digest became clear and semi-dried. Then, the samples were cooled, reconstituted to $70 \mathrm{ml}$ volume with deionized autoclaved water, filtered through Whatman No. 42 filter paper and stored at ambient temperature, in closed acid-washed glass vials. All experiments were done in triplicate for precision and accuracy of the results.

\section{Atomic Absorption Spectrometry Procedure for herbal sample analysis}

(AAS):

The stored samples were used for the analysis of heavy metals. Total content of $\mathrm{Cd}, \mathrm{Cr}, \mathrm{Cu}, \mathrm{Pb}$, and $\mathrm{Zn}$ in the edible parts of the six selected medicinal plants was determined according to the dithizone method (AOAC, 2005) with the spectrophotometer HACH DR 3900 in the laboratory of Biotechnology and Environment of the University of Yaounde I. All experiments were done in triplicate for precision and accuracy of the results. Concentration of each metal was determined from absorbance value of each replicate and articulated in $\mathrm{mg} / \mathrm{kg}$ on a dry-weight basis of the plant sample. Concentrations obtained in samples from different plant parts were compared with established safe limits of the WHO for Cd and $\mathrm{Pb}$, China for $\mathrm{Cu}$ and Canadian standard guidelines for $\mathrm{Cr}$ (1998).

\section{Statistical analysis}

The data, based on triplicate analysis were subjected to a two-way analysis of variance to bring out the effects of the plant's location on their mineral content as well as the effect the plant itself had on its mineral content. Variations among the locations, and plant samples were evaluated by means of least significance difference (LSD) at $5 \%$ level of probability $(p \leq 0.05)$. Data analysis was conducted using $\mathrm{R}$ statistical software.

\section{Results}

The results obtained (Table 2) show that all heavy metals studied in Douala were present to greater or lesser extents in different organs and collection sites of the selected medicinal plant species. Heavy metals were recorded in this range: roots $>$ leaves $>$ shoots. Sites were affected $(p<0.05)$ by the concentration of all the metals with highest level observed in $\mathrm{RS}$ and $\mathrm{RD}$, and the lowest in RA.

\section{Concentrations of heavy metals}

\section{Lead $(\mathbf{P b})$}

The concentration of $\mathrm{Pb}$ in plants from Douala varied from $3.02 \pm 0.02 \mathrm{mg} / \mathrm{kg}$ to $40.00 \pm 0.03 \mathrm{mg} / \mathrm{kg}$, with a mean value of $13.95 \pm 8.73 \mathrm{mg} / \mathrm{kg}$. Generally for all plant species, $\mathrm{Pb}$ contents ranged as follows: Cleome ciliata $>$ Ageratum conyzoides $>$ Eremomastax speciosa $>$ Justicia secunda $>$ Cymbopogon citratus $>$ Aloe vera. The roots of Cleome ciliata from RS contained the highest level $(40.00 \pm 0.03 \mathrm{mg} / \mathrm{kg})$ of $\mathrm{Pb}$, and the shoots of Aloe vera from RA had the least level $(13.95 \pm 8.73 \mathrm{mg} / \mathrm{kg})$. There very highly $(p<0.0001)$ significant difference of $\mathrm{Pb}$ concentrations between plant parts studied in Douala. There was a highly significant difference $(p<0.0001)$ in the data of roots and leaves, shoots and leaves, and a very highly significant difference $(p<0.0001)$ in the data of root and shoots. From all the plants in all locations, the mean concentrations recorded from the roots were more than those recorded from the leaves followed by shoots. Among locations, $\mathrm{Pb}$ mean content was $7.42 \pm 2.77 \mathrm{mg} / \mathrm{kg}$ from RA, $21.72 \pm 10.23 \mathrm{mg} / \mathrm{kg}$ from RS and $12.72 \pm 3.79 \mathrm{mg} / \mathrm{kg}$ from RD. Generally, very highly significant difference $(p<0.0001)$ of $\mathrm{Pb}$ concentrations were observed between all the three locations in Douala city. They were higher $(p<0.05) \mathrm{Pb}$ concentration from RS than RD and RA. However, the decreasing order of $\mathrm{Pb}$ samples in all sites was $\mathrm{RS}>\mathrm{RD}>\mathrm{RA}$. Plants harvested in $\mathrm{RD}$ had very higher $(p<0.001) \mathrm{Pb}$ values than RA and those of RD were lower $(p<0.05)$ as compared with those from RS (Fig. 8).

Plant samples collected from RA and RD contained $\mathrm{Pb}$ and $\mathrm{Cr}$ concentrations that exceeded the maximum permissible limits defined by the WHO (1998). However Cymbopogon citratus and Aloe vera samples harvested from RA were below the permissible limits. The prescribed limit for $\mathrm{Pb}$ contents in herbal medicine is 10 $\mathrm{mg} / \mathrm{kg}$ dry weight while the dietary intake limit for $\mathrm{Pb}$ is $3 \mathrm{mg} /$ week. Naithani and Kakkar (2006) in India found 
that the mean of $\mathrm{Pb}$ in the 5 medicinal plants studied was $6,39 \mathrm{mg} / \mathrm{kg}$ which is below the permissible limit of $\mathrm{Pb}$. Maximum levels of $14.4 \mathrm{mg} / \mathrm{kg}$ and $21.7 \mathrm{mg} / \mathrm{kg}$ of lead were also reported in Egyptian and Iranian spices and medicinal plants, respectively ( $\mathrm{Li}$ et al., 2012; Ziarati, 2012).

Lead is a non-essential heavy metal and is known to be one of the highly toxic environmental pollutants. The main source of $\mathrm{Pb}$ in plant parts is the soil on which they grow, which can be contaminated from several sources. The industrial (smelting process), gas emission from heavy traffic on roads (Atayese et al., 2009), agricultural (application of insecticides) and urban activities (combustion gasoline) can contribute to lead levels in soil (Falahi et al., 2013; Nookabkaew et al., 2006). It can complex with various biomolecules and adversely affect their functions. Lead exposure at low doses in the body causes colic, brain and kidneys damage, headache, anemia, miscarriage, lower sperm count, convulsions, chronic nephritis of the kidneys, central nervous system disorder, immune, renal, muscular and gastro-intestinal symptoms. Exposures to lead at prenatal and early childhood are associated with slowed cognitive development, learning deficits, and many other effects (Rehman et al., 2013).

Table 2. Mean and standard deviation concentrations of trace metals in plant parts (leaves, shoots and roots) collected from Douala.

\begin{tabular}{|c|c|c|c|c|c|c|c|}
\hline & \multirow{2}{*}{ Plants } & \multirow{2}{*}{$\begin{array}{l}\text { Plant } \\
\text { parts }\end{array}$} & \multicolumn{5}{|c|}{ Heavy metals (mg/kg) } \\
\hline & & & $\mathbf{P b}$ & Cd & $\mathrm{Cr}$ & Zn & $\mathbf{C u}$ \\
\hline \multirow[t]{9}{*}{$\mathrm{RA}$} & Aloe vera Linn. & Leaves & $6.79 \pm 0.06^{\mathrm{a}}$ & $6.03 \pm 0.05^{\mathrm{a}}$ & $0.12 \pm 0.02^{\mathrm{a}}$ & $4.28 \pm 0.03^{\mathrm{a}}$ & $20.06 \pm 0.08^{a}$ \\
\hline & & Roots & $8.64 \pm 0.04^{\mathrm{a}}$ & $7.10 \pm 0.07^{\mathrm{a}}$ & $1.83 \pm 0.03^{\mathrm{a}}$ & $8.16 \pm 0.01^{\mathrm{a}}$ & $24.43 \pm 0.05^{\mathrm{a}}$ \\
\hline & & Shoots & $3.20 \pm 0.04^{\mathrm{a}}$ & $6.36 \pm 0.05^{\mathrm{a}}$ & $0.05 \pm 0.01^{\mathrm{a}}$ & $2.29 \pm 0.02^{\mathrm{a}}$ & $14.39 \pm 0.05^{\mathrm{a}}$ \\
\hline & Cymbopogon citratus & Leaves & $8.65 \pm 0.10^{b}$ & $6.14 \pm 0.03^{b}$ & $0.09 \pm 0.03^{b}$ & $4.38 \pm 0.02^{b}$ & $19.58 \pm 0.04^{\mathrm{b}}$ \\
\hline & Stapf. & Roots & $11.73 \pm 0.05^{\mathrm{b}}$ & $7.37 \pm 0.03^{b}$ & $2.35 \pm 0.05^{b}$ & $9.46 \pm 0.03^{b}$ & $28.43 \pm 0.03^{b}$ \\
\hline & & Shoots & $5.50 \pm 0.04^{\mathrm{b}}$ & $6.44 \pm 0.06^{b}$ & $0.03 \pm 0.00^{b}$ & $1.60 \pm 0.55^{b}$ & $13.09 \pm 0.05^{b}$ \\
\hline & Ageratum & Leaves & $14.90 \pm 0.10^{\mathrm{c}}$ & $6.63 \pm 0.02^{a b}$ & $11.70 \pm 0.04^{\mathrm{c}}$ & $8.52 \pm 0.03^{c}$ & $44.13 \pm 0.04^{\mathrm{c}}$ \\
\hline & conyzoides Linn. & Roots & $27.50 \pm 0.08^{c}$ & $7.91 \pm 0.06^{\mathrm{c}}$ & $16.90 \pm 0.035^{\mathrm{c}}$ & $14.97 \pm 0.04^{\mathrm{c}}$ & $51.86 \pm 0.01^{\mathrm{c}}$ \\
\hline & & Shoots & $10.18 \pm 0.09^{c}$ & $5.52 \pm 0.05^{c}$ & $6.08 \pm 0.04^{c}$ & $9.28 \pm 0.04^{c}$ & $30.20 \pm 0.04^{c}$ \\
\hline \multirow[t]{6}{*}{$\mathrm{RS}$} & Cleome ciliata & Leaves & $22.70 \pm 0.06^{\mathrm{d}}$ & $6.27 \pm 0.03^{a b}$ & $8.16 \pm 0.08^{b d}$ & $9.10 \pm 0.05^{\mathrm{d}}$ & $35.19 \pm 0.04^{\mathrm{d}}$ \\
\hline & Schum. & Roots & $40.00 \pm 0.06^{\mathrm{d}}$ & $8.70 \pm 0.03^{b}$ & $13.28 \pm 0.05^{b}$ & $12.22 \pm 0.03^{b}$ & $49.96 \pm 0.03^{d}$ \\
\hline & & Shoots & $15.07 \pm 0.06^{\mathrm{d}}$ & $3.16 \pm 0.07^{\mathrm{d}}$ & $5.59 \pm 0.02^{d}$ & $4.59 \pm 0.03^{\mathrm{d}}$ & $27.09 \pm 0.02^{\mathrm{d}}$ \\
\hline & Eremomastax & Leaves & $11.28 \pm 0.04^{\mathrm{e}}$ & $7.27 \pm 0.04^{c}$ & $4.25 \pm 0.01^{\mathrm{e}}$ & $4.59 \pm 0.02^{\mathrm{e}}$ & $44.31 \pm 0.02^{a}$ \\
\hline & speciosa & Roots & $19.83 \pm 0.0^{\mathrm{a}}$ & $9.22 \pm 0.03^{\mathrm{d}}$ & $7.40 \pm 0.02^{d}$ & $7.36 \pm 0.06^{b}$ & $60.30 \pm 0.04^{e}$ \\
\hline & & Shoots & $10.40 \pm 0.06^{\mathrm{e}}$ & $5.73 \pm 0.03^{\mathrm{e}}$ & $2.52 \pm 0.03^{e}$ & $2.34 \pm 0.52^{\mathrm{e}}$ & $37.25 \pm 0.04^{\mathrm{e}}$ \\
\hline \multirow[t]{3}{*}{$\mathrm{RD}$} & Justicia secunda & Leaves & $10.45 \pm 0.03^{\mathrm{f}}$ & $8.61 \pm 0.59^{d}$ & $2.46 \pm 0.02^{f}$ & $5.26 \pm 0.03^{f}$ & $66.46 \pm 0.04^{e}$ \\
\hline & Vahl. & Roots & $15.13 \pm 0.08^{e}$ & $10.32 \pm 0.03^{\mathrm{e}}$ & $5.07 \pm 0.03^{e}$ & $9.93 \pm 0.03^{\mathrm{bcd}}$ & $71.19 \pm 0.03^{f}$ \\
\hline & & Shoots & $9.22 \pm 0.09^{f}$ & $7.10 \pm 0.04^{\mathrm{a}}$ & $1.26 \pm 0.04^{f}$ & $3.36 \pm 0.03^{f}$ & $41.33 \pm 0.04^{\mathrm{f}}$ \\
\hline \multicolumn{2}{|c|}{ Permissible limits } & & 10 & 0.3 & 2 & 27.4 & 20 \\
\hline
\end{tabular}

\section{Cadmium}

The cadmium (Cd) concentrations in Douala (Table 2) were in the range from $3.16 \pm 0.07 \mathrm{mg} / \mathrm{kg}$ to $10.32 \pm 0.03$ $\mathrm{mg} / \mathrm{kg}$ for all the samples, with a mean value of $6.99 \pm 1.58 \mathrm{mg} / \mathrm{kg}$. Of all the selected plant species, the highest concentrations of $\mathrm{Cd}$ were noticed in Justicia secunda followed by Eremomastax speciosa, Ageratum conyzoides, Cymbopogon citratus, Aloe vera and Cleome ciliata in decreasing order of concentrations. Among the plant parts, the highest concentration was recorded from the roots of Justicia secunda $(10.32 \pm 0.03 \mathrm{mg} / \mathrm{kg})$ harvested from RD and the lowest mean value was recorded from the shoots of Cleome ciliata $(3.16 \pm 0.07$ $\mathrm{mg} / \mathrm{kg}$ ) harvested from RD. Cd concentrations showed very highly $(p<0.0001)$ significant difference between plant parts studied in Douala. Thus there was a highly significant difference $(p<0.0001)$ between roots and leaves, shoots and leaves, and a light significant difference $(p<0.05)$ in the data of roots and shoots. Overall in all the studied plants, $\mathrm{Cd}$ concentration was recorded in this range: roots $>$ leaves $>$ shoots. Amongst locations, Cd mean content was $6.57 \pm 0.51 \mathrm{mg} / \mathrm{kg}$ from RA, $6.36 \pm 1.83 \mathrm{mg} / \mathrm{kg}$ from RS and $8.04 \pm 1.57 \mathrm{mg} / \mathrm{kg}$ 
from $\mathrm{RD}$. The trend of $\mathrm{Cr}$ concentration in plants from RA and RS were similar but lower $(p<0.05)$ than in those from RD. Cd repartition based on the collection site was as follows: $\mathrm{RD}>\mathrm{RA} \geq \mathrm{RS}$. Plants harvested at $\mathrm{RD}$ had very higher $(p<0.05) \mathrm{Cd}$ values than those collected from RA and RS (Fig. 8). The experimental results showed that $100 \%$ of the samples analyzed had Cadmium concentrations that exceeded the permissible limit defined by the WHO (2005); prescribed limit for Cd contents in medicinal plant is $0.3 \mathrm{mg} / \mathrm{kg}$ and the maximum acceptable concentration for food stuff is around $1 \mathrm{ppm}$. Similar results of high levels of cadmium in Egyptian, Nigerian, Eritrean and Sud African medicinal herbs and plants have been reported in earlier studies (Abou Arab and Abou Donia, 2000; Yusufa et al., 2003; Sium et al., 2016; Lion et al., 2016).

Cadmium is a non-essential trace element having functions neither in human body nor in plants. It is extremely toxic even at low concentration. The high levels of cadmium exercise a serious toxicological effect on human health. It causes learning disabilities and hyperactivity in children. Cadmium accumulates in human body and damages mainly the kidneys and liver. $\mathrm{Cd}$ intoxication can therefore lead to kidney, bone and pulmonary damages (Godt et al., 2006). At high concentrations, cadmium produces serious effects on the liver and vascular and immune systems (Neil, 1993).

\section{Chromium}

The mean concentration of $\mathrm{Cr}$ (Table 2) found in different samples of Douala was $4.95 \pm 4.84 \mathrm{mg} / \mathrm{kg}$ and $\mathrm{Cr}$ content varied from $0.03 \pm 0.00 \mathrm{mg} / \mathrm{kg}$ to $16.90 \pm 0.04$ $\mathrm{mg} / \mathrm{kg}$ in all plant species studied. The highest concentration of $\mathrm{Cr}$ contents was found in Ageratum conyzoides followed by Cleome ciliata, Eremomastax speciosa, Justicia secunda, Cymbopogon citratus and Aloe vera. High concentration of $\mathrm{Cr}$ occurred in the roots of Ageratum conyzoides $(16.90 \pm 0.04 \mathrm{mg} / \mathrm{kg}$ ) harvested from RS while low concentration was found in the shoots of Cymbopogon citratus $(0.03 \pm 0.00 \mathrm{mg} / \mathrm{kg})$ from RA. $\mathrm{Cr}$ concentrations showed highly $(p<0.05)$ significant difference between plant parts, probably due to the absorption of $\mathrm{Cr}$ contents from the polluted air. There was no significant difference $(p>0.05)$ between roots and leaves and between shoots and leaves. However, there was a highly significant difference $(p<0.05)$ between the data from roots and shoots. From all the plants in all locations, the mean concentrations recorded from the roots were more than those recorded from the shoots followed by leaves.
The experimental data revealed that $\mathrm{Cr}$ mean content was $0.75 \pm 0.99 \mathrm{mg} / \mathrm{kg}$ in samples from RA, $10.28 \pm 4.18$ $\mathrm{mg} / \mathrm{kg}$ for $\mathrm{RS}$ and $3.83 \pm 2.09 \mathrm{mg} / \mathrm{kg}$ for RD. The $\mathrm{Cr}$ repartition based on collection sites was as follows: $\mathrm{RS}>\mathrm{RD}>\mathrm{RA}$. There was a very highly $(p<0.0001)$ significant difference in $\mathrm{Cr}$ contents between different habitats studied in Douala and the results showed very higher significant levels $(p<0.001)$ of $\mathrm{Cr}$ concentrations in plant samples obtained from RS compared with those obtained from RD and RA. All plants collected from RD had higher $(p<0.05)$ Cd values than those collected in RA (Fig. 8).

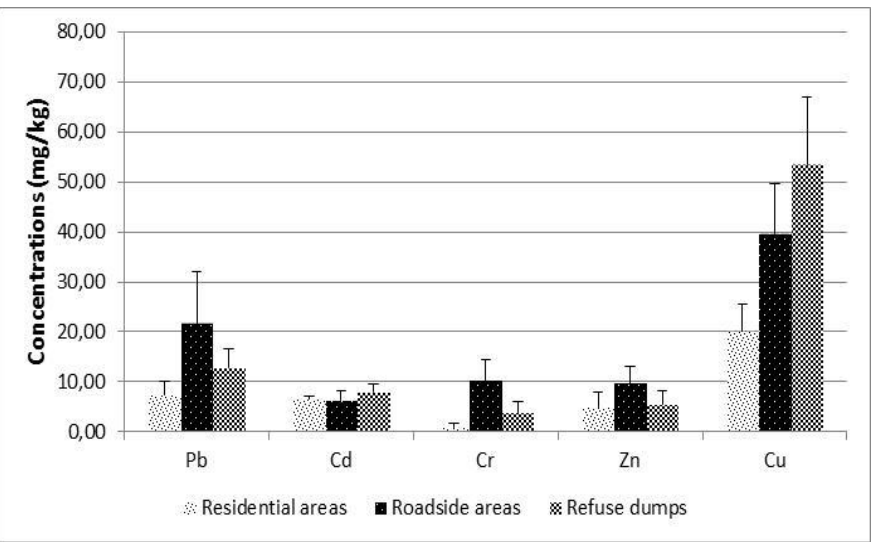

Fig. 8: Heavy metals' contents $(\mathrm{mg} / \mathrm{kg})$ in the medicinal plant samples from different geographical locations in Douala.

There are no established WHO concentration limits for $\mathrm{Cr}$ in medicinal plants. However, permissible limits for $\mathrm{Cr}$ in medicinal plants set by Canada are $2 \mathrm{mg} / \mathrm{kg}$ in raw medicinal plant materials (WHO, 2005) and the daily intake of Cr 50-200 $\mu \mathrm{g}$ has been recommended for adults by US National Academy of Sciences (Waston, 1993). Plants collected from RS and RD were higher than the permissible limit of $2 \mathrm{mg} / \mathrm{kg}$ as set by Canadian standards while those harvested from RA did not exceed that permissible limit. The toxic effects of $\mathrm{Cr}$ intake are skin rashes, nose irritation, bleeding, stomach ache, kidney and liver damage and cancer. Chromium deficiency is characterized by disturbance in glucose lipids and protein metabolism (McGrath \& Smith, 1990; Khan et al., 2010). Sources of $\mathrm{Cr}$ in the deposited dust may be due to natural weathering and wind deflation or anthropogenic emission from the industries and vehicles.

\section{Zinc}

The range and mean concentrations of $\mathrm{Zn}$ found in samples during this study were $1.60 \pm 0.55 \mathrm{mg} / \mathrm{kg}-$ $14.97 \pm 0.04 \mathrm{mg} / \mathrm{kg}$ and $6.76 \pm 3.63 \mathrm{mg} / \mathrm{kg} \quad \mathrm{DW}$ respectively (Table 2). In all plant species, the $\mathrm{Zn}$ 
contents ranged as follows: Ageratum conyzoides> Cleome ciliata $>$ Justicia secunda> Cymbopogon citratus $>$ Aloe vera>Eremomastax speciosa. The roots of Ageratum conyzoides from RS contained the maximum amount $(14.97 \pm 0.04 \mathrm{mg} / \mathrm{kg})$ of $\mathrm{Zn}$ while the shoots of Cymbopogon citratus $(1.60 \pm 0.55 \mathrm{mg} / \mathrm{kg})$ from RA had the minimum amount of $\mathrm{Zn}(14.97 \pm 0.04 \mathrm{mg} / \mathrm{kg})$. It may be due to the absorption of the metals from the polluted soils. Concentration of $\mathrm{Zn}$ varied in different plant organs and the differences obtained in leaves, shoots and roots of all the plants were highly significant $(p<0.0001)$. So there were higher $\mathrm{Zn}$ concentrations $(p<0.0001)$ in roots than leaves and shoots respectively. The transportation of $\mathrm{Zn}$ was found in the order roots>shoots>leaves which are in line with results from Das et al. (2001) and Bhattacharya et al. (2013). The mean content of $\mathrm{Zn}$ was $5.03 \pm 2.97 \mathrm{mg} / \mathrm{kg}$ in samples from RA, followed by $9.78 \pm 3.31 \mathrm{mg} / \mathrm{kg}$ for RS samples and then $5.47 \pm 2.61 \mathrm{mg} / \mathrm{kg}$ for $\mathrm{RD}$. The repartition of $\mathrm{Zn}$ based on the collection sites was as follows: RS $>$ RD $>$ RA. There was a very highly significant difference of $\mathrm{Zn}$ between the different sites studied in Douala $(p<0.0001)$. The trend of $\mathrm{Zn}$ concentration in samples from RD and RA were practically similar but lower $(p<0.0001)$ than in those from RS (Fig. 8). RS plants had the highest $(p<0.001)$ values of $\mathrm{Zn}$ possibly due to the high vehicle traffic.

The WHO limits are not yet established for $\mathrm{Zn}$ in medicinal plants. However, the permissible limit set by FAO/WHO (1989) in edible plants is $27.4 \mathrm{mg} / \mathrm{kg}$. In this study, all harvested plants widely exceeded the permissible limit of $\mathrm{Zn}$ except for Ageratum conyzoides which was below that value. Zinc is an essential trace element for plant growth and also plays an important role in various cell processes including normal growth, brain development, behavioral response, bone formation and wound healing. Zinc deficient diabetics fail to improve their power of perception and also lose the sense of touch and smell (Hunt, 1994).

\section{Copper}

As can be seen from the data (table 2), the mean concentration of $\mathrm{Cu}$ obtained in this study was $37.74 \pm 17.05 \mathrm{mg} / \mathrm{kg} \mathrm{DW}$ and $\mathrm{Cu}$ varied between $13.09 \pm 0.05 \mathrm{mg} / \mathrm{kg}$ and $71.19 \pm 0.03 \mathrm{mg} / \mathrm{kg}$. The average $\mathrm{Cu}$ concentration $(\mathrm{mg} / \mathrm{kg})$ trend for medicinal plants studied was Justicia secunda>Eremomastax speciosa> Ageratum conyzoides $>$ Cleome ciliata $>$ Cymbopogon citratus $>$ Aloe vera. There was very highly significant difference $(p<0.0001)$ of $\mathrm{Cu}$ between the plant species studied in Douala. The highest mean value was recorded from the roots of Justicia secunda $(71.19 \pm 0.03 \mathrm{mg} / \mathrm{kg})$ obtained from soil collected from RD. The lowest mean value was recorded from the shoots of Cymbopogon citratus $(13.09 \pm 0.05 \mathrm{mg} / \mathrm{kg})$ harvested from soil collected from RA. However, $\mathrm{Cu}$ concentrations showed highly significant difference $(p<0.0001)$ between plant parts studied in Douala. There was a very highly significant difference $(p<0.0001)$ between roots and shoots and a highly significant difference $(p<0.05)$ in the roots and leaves, shoots and leaves. From all the plants in all locations, the mean concentrations recorded from the roots were more than those recorded from the shoots, followed by leaves.

Among locations, $\mathrm{Cu}$ mean content was $20.00 \pm 5.48$ $\mathrm{mg} / \mathrm{kg}$ from RA, $39.74 \pm 9.78 \mathrm{mg} / \mathrm{kg}$ from RS and $53.47 \pm 13.44 \mathrm{mg} / \mathrm{kg}$ from $\mathrm{RD}$. The $\mathrm{Cu}$ repartition based on the collection site was as follows: RD $>$ RS $>$ RA. There was a very highly significant difference $(p<0.0001)$ in $\mathrm{Cu}$ contents between different study sites in Douala. Plants collected from $\mathrm{RD}$ had higher $(p<0.001) \mathrm{Cu}$ values than those collected from RS and RA respectively. However, there was significant variation in the values of $\mathrm{Cu}$ obtained from RS and RA ( $p<0.05)$ (Fig. 8). The high concentrations of $\mathrm{Cu}$ in the roots of plant led to two hypotheses: (i) it may be due to higher absorption ability of the plants to get the trace heavy metals from the polluted soils, or (ii) it may be due to the presence of higher amounts of copper in the respective soil samples. In this light, Justicia secunda plants have the highest ability to absorb the metals from the soil.

Although $\mathrm{Cu}$ is an essential enzymatic element for normal plant growth and development, it can be toxic at excessive levels. High intakes of copper are detrimental to human health and may cause fever with flue like symptoms, hair and skin decoloration, dermatitis, irritation of the upper respiratory tract, metallic taste in the mouth and nausea, and some other fatal diseases in human beings (Khan et al., 2008). Copper deficiency results in anemia and congenital inability to excrete copper resulting in Wilson's disease (Gupta. 1975). Therefore, $\mathrm{Cu}$ content in medicinal plants must be controlled on a daily basis (Karak and Bhagat, 2010). However for medicinal plants, the WHO limits are not yet established for copper. Although in medicinal plants, permissible limits for copper set by China and Singapore, are $20 \mathrm{ppm}$ and $150 \mathrm{ppm}$ respectively (WHO, 2005). In this study, all harvested plants widely exceeded this permissible limit of China (20.00 mg/kg), except for Ageratum conyzoides which was below that value. Maximum levels of $\mathrm{Cu}$ were also 
reported in Eritrea by Sium et al. (2016) and South African medicinal plants, respectively (Lion et al., 2016). High concentrations of $\mathrm{Cu}$ and the other trace heavy metals present in the underground parts of the plants may be due to the absorption ability of the plants to get the trace heavy metals from the polluted soils. $\mathrm{Cu}$ contamination could mainly originate from vehicles and fungicides (Han et al., 2006).

\section{Discussion}

Overall comparison of the metal contents in medicinal plants in some other parts of the world revealed that the levels are generally comparable in Cameroon and elsewhere. This trend could be ascribed to the high values of studied heavy metal $(\mathrm{Pb}, \mathrm{Cd}, \mathrm{Cr}, \mathrm{Zn}$ and $\mathrm{Cu})$ concentrations present in the studied plants. Six plant species were assessed for metal accumulation in their different parts in Douala where plant samples were collected from RA (Cymbopogon citratus and Aloe vera), RS (Cleome ciliata and Ageratum conyzoides) and $\mathrm{RD}$ (Eremomastax speciosa and Justicia secunda).

The results showed a significant difference in the contents of metals in all plants from different sites $(p<0.0001)$. The study reveals that heavy metal pollution of the selected plants is significant in the Douala region. It also points to $\mathrm{RD}$ as the most important source of contamination. Samples collected from RS zones showed significantly higher concentration of heavy metals followed by RD and then RA. A study of Deepalakshmi et al. (2014), who evaluated the potential for accumulation of heavy metals in roadside plants in the city of Bangalore (India) found high values of $\mathrm{Pb}(84.98 \pm 0.11 \mathrm{mg} / \mathrm{g}), \mathrm{Cu}(55.64 \pm 0.17$ $\mathrm{mg} / \mathrm{g}), \mathrm{Zn}(80.34 \pm 0.26 \mathrm{mg} / \mathrm{g}), \mathrm{Cd}(9.56 \pm 0.25 \mathrm{mg} / \mathrm{g})$ in Ageratum conyzoides. Messou et al. (2013) obtained similar results in their research: $\mathrm{Pb}(48.98 \pm 0.11 \mathrm{mg} / \mathrm{g})$, $\mathrm{Cr}(6.56 \pm 0.35 \mathrm{mg} / \mathrm{g}), \mathrm{Cu}(59.94 \pm 0.34 \mathrm{mg} / \mathrm{g}), \mathrm{Zn}(67.34$ $\pm 0.16 \mathrm{mg} / \mathrm{g}$ ). Effiong (2013) in the southwestern region of Nigeria suggested that average levels of $\mathrm{Cu}$ and $\mathrm{Pb}$ at the refuse dump sites were significantly higher than other locations (industrial waste dump sites, industrial areas, residential areas, around an effluent channel). In this study, metal levels at the residential areas were about the levels in the control. Generally, the degree of contamination within the vicinity of the site was of the order $\mathrm{Cu}>\mathrm{Pb}>\mathrm{Cd}>\mathrm{Cr}$. It can be stated that the site of growth noticeably influences heavy metal uptake by the six plant varieties assessed in this study.

Several factors control the selective accumulation of metals in plant and their bioavailability: soil and climatic conditions, plant genotype and agronomic techniques (Chunilall et al., 2005). The traffic flow also had a significant effect on the content of heavy metals in plants growing along the road. Further away from the road, and under lower traffic flow intensity, the amounts of contaminants originating from vehicle traffic decreased. Emissions of trace elements depend on the differences in the traffic flow intensity, number, type, and speed of vehicles and on the atmospheric conditions as well as the distribution of buildings (Modrzewska et al., 2014). Annan et al. (2013) reported that the 5 minerals namely: $\mathrm{Pb}, \mathrm{As}, \mathrm{Hg}, \mathrm{Cd}$ and $\mathrm{Al}$ were present in 10 medicinal plants sampled from 5 different geographical locations in Ghana and a significant variation existed in mineral content for the various locations $(p \leq 0.05)$.

In the present study, most of the plant parts harvested from the refuse dump sites had significant and high values of all heavy metals studied. Ebong (2007) found that concentrations of the metals in the dump site soil and plant parts in Nigeria were higher and significant differences of heavy metals' (Cu. Zn. Pb. Cd) accumulation were observed between plant parts. This could be attributed to the high metal contents in the dump site soils which were eventually accumulated by plants grown on them. This also indicates that the concentrations of metals in plants are dependent upon their concentrations in the soil on which they grow.

\section{Permissible limits of heavy metals}

All the plants studied exceeded the different permissible limits of $\mathrm{Pb}, \mathrm{Cd}, \mathrm{Cr}, \mathrm{Zn}$ and $\mathrm{Cu}$ except for Ageratum conyzoides which was below the $\mathrm{Cu}$ value. But since the metal accumulation and translocation potential varied between different metals and vegetables and did not follow any particular pattern, their impact on health needs should be evaluated based on the elements that surpassed the maximum limit (Manzoor et al., 2006; Tiwari et al., 2011; Nabulo et al., 2011; Weldegebriel et al., 2011). A similar investigation was conducted for plants obtained from Bahrain, and Nigeria. In Bahrain, Al-Saleh and Chudasama (1994) reported that a large portion of the plants examined contained high concentrations of toxic metals and some of them exceeded the limits of toxicity; the reported data indicate a potential health hazard. Nwoko et al., (2011) showed that the $\mathrm{Zn}, \mathrm{Cd}$ and $\mathrm{Pb}$ contents of selected ready-to-use herbal remedies in South-east Nigeria were beyond WHO permissible limits. The health risk due to metal contamination, in general, depends on the average daily dietary intake (Dghaim et al., 2015). 


\section{Plant parts}

The results obtained in this study show that concentrations of $\mathrm{Cu}$ and $\mathrm{Zn}$ were highest in all the plants studied and that the plants accumulated more of the trace metals in their roots than in shoots. The ability of plants to bioaccumulate more trace metals in their roots than the shoot has been reported in literature. The study of Lion et al. (2016) observed that from all the plants studied, the concentrations of trace metals in the roots were more than those recorded in the shoot with a significant difference $(p<0.05)$. Hazrat et al. (2012) showed that the concentrations of trace metals were greater in roots than in shoots. A similar observation was also made by Peralta et al. (2001) where alfalfa plants accumulated more of the trace metals in the roots than any other part.

Different vegetable species accumulated different metals depending on environmental conditions, metal species and plant available forms of heavy metals. Plants have a natural propensity to take up and maintain metals at relatively low concentrations by avoiding excessive metal uptake and transport (McGrath et al., 2001). Some metals like $\mathrm{Cu}, \mathrm{Co}, \mathrm{Fe}, \mathrm{Mo}, \mathrm{Mn}, \mathrm{Ni}$ and $\mathrm{Zn}$, are essential mineral nutrients, while $\mathrm{Cd}$ and $\mathrm{Pb}$, have no known physiological activity (McGrath et al., 2001).

\section{Conclusion}

Heavy metal contamination in the environment is of more concern worldwide. The results of the present assessment showed that the selected medicinal plants are good absorbers of metals; and concentration of minerals depends on the different geographical conditions as well as their components. This study proved that plants overgrowing in GS and RS soils accumulate much higher amounts of $\mathrm{Cd}, \mathrm{Pb}, \mathrm{Cr}, \mathrm{Cu}$, and $\mathrm{Zn}$ than the plants from RA. The highest contents of heavy metals were found in the roots, but their levels in the leaves and shoots were elevated as well, implying a risk of transport of toxicants along the food chain. It may be due to geological strata or pollution of the studied area. The assay of heavy metals varied from site to site, plant to plant, and also in different parts of each plant, depending upon the chemical composition of soil and absorption rate by plants. Thus, it is essentially required that every medicinal plant should be checked for contaminant load before processing for further pharmaceutical purposes or for local human consumption. This study also concluded that those plants can also be used for the removal of heavy metal from the soil and waste water because they have the capacity to absorb the metals from the soil.
Generally, the concentration of heavy metals in the different parts of Eremomastax speciosa followed the order $\mathrm{Cu}>\mathrm{Pb}>\mathrm{Cd}>\mathrm{Zn}>\mathrm{Cr}$ in shoots and roots compared to leaves. Justicia secunda accumulated $\mathrm{Cu}>\mathrm{Pb}>\mathrm{Cd}>$ $\mathrm{Zn}>\mathrm{Cr}$ in roots, shoots and leaves. In Cymbopogon citratus, $\mathrm{Cu}>\mathrm{Pb}>\mathrm{Zn}>\mathrm{Cd}>\mathrm{Cr}$ accumulation was observed in roots, $\mathrm{Cu}>\mathrm{Pb}>\mathrm{Cd}>\mathrm{Zn}>\mathrm{Cr}$ in leaves and $\mathrm{Cu}>\mathrm{Pb}>\mathrm{Cd}>\mathrm{Zn}>\mathrm{Cr}$ in plant shoot. In Aloe vera, the concentration decreasing pattern of metals was $\mathrm{Cu}>\mathrm{Pb}$ $>\mathrm{Zn}>\mathrm{Cd}>\mathrm{Cr}$ in roots, $\mathrm{Cu}>\mathrm{Pb}>\mathrm{Cd}>\mathrm{Zn}>\mathrm{Cr}$ in leaves and $\mathrm{Cu}>\mathrm{Cd}>\mathrm{Pb}>\mathrm{Zn}>\mathrm{Cr}$ in shoots. Cleome ciliata followed the order $\mathrm{Cu}>\mathrm{Pb}>\mathrm{Cr}>\mathrm{Zn}>\mathrm{Cd}$ in roots and shoots and $\mathrm{Cu}>\mathrm{Pb}>\mathrm{Zn}>\mathrm{Cr}>\mathrm{Cd}$ in leaves. Ageratum conyzoides followed the order $\mathrm{Cu}>\mathrm{Pb}>\mathrm{Cr}>$ $\mathrm{Zn}>\mathrm{Cd}$ in roots and leaves and $\mathrm{Cu}>\mathrm{Pb}>\mathrm{Zn}>\mathrm{Cr}>\mathrm{Cd}$ in shoots.

\section{Conflict of interest statement}

Authors declare that they have no conflict of interest.

\section{Acknowledgement}

This work was carried out with financial support from the International Foundation for Science (IFS), Grant No. D/5771-1. The authors are grateful to Mr. Pierre Mkounga of the Laboratory of Organic Chemistry of the University of Yaounde I for his assistance in this work.

\section{References}

Abou-Arab, A.A.K., Abou Donia, M.A., 2000. Heavy metals in Egyptian spices and medicinal plants and the effect of processing on their levels. J. Agric. Food Chem. 48, 23002304.

Adepoju-Bello, A.A., Issa, O.A., Oguntibeju, O.O., Ayoola, G.A., Adejumo, O.O., 2014. Analysis of some selected toxic metals in registered herbal products manufactured in Nigeria. Afr. J. Biotech. 11(26), 6918-6922.

Al-Saleh, F. S., Chudasama, S., 1994. Trace metal concentrations in the medicinal plants of the flora of Bahrain. Toxicol. Environ. Chem. 46(1-2), 1-9.

Annan, K., Dickson, R.A., Amponsah, I.K., Nooni, I.K., 2013. The heavy metal contents of some selected medicinal plants sampled from different geographical locations. Pharmacogn. Res. 5, 103-108.

AOAC International, 2005. Official methods of analysis of AOAC International. 18th Edn.

Atayese, M.O., Eigbadon, A.I., Oluwa, K.A., Adesodun, J.K.., 2009. Heavy metal contamination of Amaranthus grown along major highways in Lagos. Afr. Crop Sci. J. 16, 225235.

Ayari, F., Hamdi, H., Jedidi, N., Kossai, R., 2010. Heavy metal distribution in soil and plant in municipal solid 
waste compost amended plots. Int. J. Environ. Sci. Technol. 7, 465-472.

Calixto, B.J., 2000. Efficacy, safety, quality control, marketing and regulatory guidelines for herbal medicines (phytotherapeutic agents). Braz. J. Med. Biol. Res. 33(2), 179-189.

Chunilall, V., Kindness, A., Jonnalagadda, S.B., 2005. Heavy metal uptake by two edible Amaranthus herbs grown on soils contaminated with lead, Mercury, cadmium and nickel. J. Environ. Sci. Health. A, 40, 375-384.

Das, P., Rout, G.R., Samantaray, S., 2001. Heavy metal and nutrient concentration in soil and plants growing on metalliferous chromite minespoil. Environ Toxicol. 22, 1147-1154.

Deepalakshmi, A. P., Ramakrishnaiah, H., Ramachandra, Y. L., Naveen Kumar, N., 2014. Leaves of higher plants as indicators of heavy metal pollution along the urban roadways. Int. J. Sci. Technol. 3(6), 340-346.

Dghaim, R., Safa, A.I., Khatib Rasool, H., Munawwar, K., 2015. Determination of heavy metals concentration in traditional herbs commonly consumed in the United Arab Emirates. J. Environ. Public Health. Article ID 973878. $6 \mathrm{p}$.

Dibong, S.D., Mpondo Mpondo, E., Ngoye, A., Kwin, M.F., Betti, J.L., 2011. Ethnobotanique et phytomédecine des plantes médicinales de Douala, Cameroun. J. Appl. Biosci. 37, 2496-2507.

Dibong, S.D., Tchatat, M., Yinyang, J., Mvogo, O.P.B., Ndjib, R.C., Mpondo, M.E., 2012. Valorisation des produits forestiers non ligneux spéciaux d'origine végétale vendus dans les marchés Est de la ville de Douala (Cameroun). J. Anim. Plant Sci. 20(1), 3067-3078.

Ebong, G., Akpan, M., Mkpenie, V., 2007. Heavy metal contents of municipal and rural dumpsite soils and rate of accumulation by Carica papaya and Talium traingulare in Uyo. Nigeria. E-J. Chem. 5(2), 282-290.

Effiong, U.E., Onianwa, P.C., 2013. Heavy metal pollution of topsoil in the vicinity of an industrial estate co-located with a housing estate in Southwestern Nigeria. J. Environ. Protect. 4, 91-98.

Falahi, E., Hedaiati, R., 2013. Heavy metal content of black teas consumed in Iran. Food Addit. Contamin.: Part B, 6(2), 123-126.

Fauziah, S.H., Hajar, W.I., Agamuthu, P., 2010. Heavy metal accumulation in plants: A case study of Ipomoea reptans and Helianthus annuus. Malay. J. Sci. 30(1), 196-199.

Fernández-Luqueño, F., López-Valdez, F., Gamero-Melo, P., Luna-Suárez, S., Aguilera-González, E.N., Martínez, A.I., García-Guillermo, M., Hernández-Martínez, G., HerreraMendoza, R., Álvarez-Garza, M.A., Pérez-Velázquez, I.R., 2013. Heavy metal pollution in drinking water - a global risk for human health: A review. Afr. J. Environ. Sci. Technol. 7, 567-584.

Fongod, A., Modjenpa, N., Veranso, M., 2013. Ethnobotany of Acanthaceae in the Mount Cameroon region. J. Med. Plants Res. 7(38), 2859-2866.

Godt, J., Scheidig, F., Grosse-Siestrup, C., Esche, V.,
Brandenburg, P., 2006. The toxicity of cadmium and resulting hazards for human health. J. Occup. Med. Toxicol. 22, 1-6.

Gupta, S., Porwal, M.C., Roy, P.S., 2004. Indigenous knowledge on some medicinal plants among the Nicobari Tribe of Car Nicobar Island. Ind. J. Trad. Knowl. 3, 287293.

Gupta, U., 1975. Copper in the environment (Ed.: Nariagu, J.O.). John Wiley and Sons, New York. 255p.

Haider, S., Naithani, V., Barthwal, J., Kakkar, P., 2004. Heavy metal content in some therapeutically important medicinal plants. Bull. Environ. Contamin. Toxicol. 72(1), 119-127.

Han, W.Y., Liang, Y.R., Yang, Y.J., Ma, L.F., Ruan, J.Y., 2006. Effect of processing on the $\mathrm{Pb}$ and $\mathrm{Cu}$ pollution of tea in China. J. Tea Sci. 26, 95-101.

Hazrat, A., Naseer, M., Sajad, M.A., 2012. Phytoremediation of heavy metals by Trifolium alexandrinum. Int. J. Environ. Sci. 2, 1459-1469.

Hseu, Z.-Y., 2004. Evaluating heavy metal contents in nine composts using four digestion methods. Bioresour. Technol. 95(1), 53-59.

Hunt, J. R., 1994. Bioavailability of Fe, $\mathrm{Zn}$ and other trace minerals for vegetarian diets. Am. J. Clin. Nutr. 78, 633639.

Ji, W., Chen, Z., Li, D., Ni, W., 2012. Identifying the criteria of cadmium pollution in paddy soils based on a field survey. Energy Procedia. 16, 27-31.

Jiofack, T., Fokunang, C., Guedje, N., Kemeuze, V., Fongnzossie, E., Nkongmeneck, B.A., Mapongmetsem, P.M., Tsabang, N., 2010. Ethnobotanical uses of medicinal plants of two ethnoecological regions of Cameroon. Int. J. Med. Med. Sci. 3(2), 60-79.

Karak, T., Bhagat, R. M., 2010. Trace elements in tea leaves, made tea and tea infusion: A review. Food Res. Int. 43, 2234-2252.

Khan, S., Cao, Q., Zheng, Y.M., Huang, Y.Z., Zhu, Y.G., 2008. Health risks of heavy metals in contaminated soils and food crops irrigated with wastewater in Beijing, China. Environ. Poll. 152(3), 686-692.

Khan, S., Rehman, S., Zeb Khan, A., Amjad Khan, M., Tahir Shah, M., 2010. Soil and vegetables enrichment with heavy metals from geological sources in Gilgit, northern Pakistan. Ecotoxicol. Environ. Saf. 73(7), 1820-1827.

Krishna, A.K., Govil, P.K., 2007. Soil contamination due to heavy metals from an industrial area of Surat. Gujarat. Western India. Environ. Monit. Assess. 124, 263-275.

Kulhari, A., Sheorayan, A., Somvir, Bajar, S., Susheel Sarkar S., Chaudhury, A., Rajwant, K., Kalia, R.K., 2013. Investigation of heavy metals in frequently utilized medicinal plants collected from environmentally diverse locations of north western India. Springer Plus. 2, 676.

Lee, S.M., Lee, W.Y., 2002. Determination of heavy metal ions using conductometric biosensor based on sol-gelimmobilized urease. Bull. Kor. Chem. Soc. 23, 11691172.

Li, S.-M., Fang, Y., Ning, H.-M., Wu, Y.X., 2012. Heavy metals in Chinese therapeutic foods and herbs. J. Chem. 
Soc. Pak. 34(5), 1091-1095.

Lion, G. N., Olowoyo, J.O., Modise, T.A., 2016. Trace metals bioaccumulation potentials of three indigenous grasses grown on polluted soils collected around mining areas in Pretoria, South Africa. West Afr. J. Appl. Ecol. 24(1), 4351.

Maharia, R.S., Dutta, R.K., Acharya, R., Reddy, A.V.R., 2012. Heavy metal bioaccumulation in selected medicinal plants collected from Khetri copper mines and comparison with those collected from fertile soil in Haridwar, India. J. Environ. Sci. Health Part B. 45, 174-148.

Manzoor, S., Shah, M.H., Shaheen, N., Khalique, A., Jaffar, M., 2006. Multivariate analysis of trace metals in textile effluents in relation to soil and ground water. J. Hazard Mater. 137, 31-37.

McGrath, S., Zhao, F., Lombi, E., 2001. Plant and rhizosphere processes involved in phytoremediation of metalcontaminated soils. Plant Soil. 232(1), 207-214.

McGrath, S.P., Smith, S., 1990. Chromium and nickel. In: Heavy Metals in Soils (Ed.: Alloway, B.J.). Blackie, Glasgow and London. pp. 125-146.

Messou, A., Coulibaly, L., Doumbia, L., Gourene, G., 2013. Plants diversity and phytoaccumulators identification on the Akouedo landfill (Abidjan, Côte d'Ivoire). Afr. J. Biotechnol. 12(3), 253-264.

Modrzewska, B., Wyszkowski, M., 2014. Trace metals content in soils along the state road 51 (northeastern Poland). Environ. Monit. Assess. 186, 2589-2597.

Mpondo, M.E., Dibong, D.S., Priso, R.J., Ngoye, A., Ladoh, Y.C.F., 2012. État actuel de la médecine traditionnelle dans le système de santé des populations rurales et urbaines de Douala (Cameroun). J. Appl. Biosci. 55, 4036-4045.

Nabulo, G., Black, C.R., Young, S.D., 2011. Trace metal uptake by tropical vegetables grown on soil amended with urban sewages ludge. Environ. Pollut. 159, 368-376.

Naithani, V., Kakkar, P., 2006. Effect of ecological variation on heavy metal content of some medicinal plants used as herbal tea ingredients in India. Bull. Environ. Contam. Toxicol. 76, 285-292.

Nawab, J., Khan, S., Shah, M.T., Islamud, Z.Q., Mahmood, D.Q., Gul, N., 2015. Contamination of soil, medicinal and fodder plants with lead and cadmium present in mineaffected areas, northern Pakistan. Environ. Monit. Assess. $187,605$.

Ndem, J. I., Otitoju, O., Akpanaiabiatu, M. I., Uboh, F. E., Uwah, A. F., Edet, O. A., 2013. Haematoprotective property of Eremomastax speciosa (Hochst.) on experimentally induced anaemic wistar rats. Ann. Biol. Res. 4(6), 356-360.

Neil, P.O., 1993. Minor Element and Environmental Problems. Environmental Chemistry. $2^{\text {nd }}$ Edn. George Allen and Unwin (Publishers) Ltd., London. pp.11-43.

Ngene, J.-P., Ngoule, C.C., Pouka, K.C., Mvogo, O.P., Ndjib, R.C., Dibong, S.D., Mpondo, M.E., 2015. Importance dans la pharmacopée traditionnelle des plantes à flavonoïdes vendues dans les marchés de Douala est
(Cameroun). J. Appl. Biosci. 88, 8194-8210.

Nies, D.H., 1999. Microbial heavy metal resistance. Appl. Microbiol. Biotechnol. 51, 730-750.

Nwoko, O.C., Mgbeahuruike, L., 2011. Heavy metal contamination of ready-to-use herbal remedies in South Eastern Nigeria. Pak. J. Nutr. 10(10), 959-964.

Oben, J.E., Assi, S.E., Agbor, G.A., Musoro, D.F., 2006. Effect of Eremomastax speciosa on experimantal diarrhea. Afr. J. Trad. CAM. 3(1), 95-100.

Okokon, J.E., Antia, B.S., Udoh, A.E., Akpan, M.M., 2007. Antianaemic and antimicrobial activity of Eremomastax speciosa. J. Pharmacol. Toxicol. 2, 196-199.

Peralta, J.R., Gardea-Torresdey, J.L., Tiemann, K.J., Gomez, E., Arteaga, S., Rascon, E., Carrillo, G., 2001. Uptake and effects of five heavy metals on seed germination and plant growth in alfalfa (Medicago sativa). Bull. Environ. Contam. Toxicol. 66, 727-734.

Priso, R.J., Nnanga, J.F., Etame, J., Din, N., Amougou, A., 2011. Les produits forestiers non ligneux d'origine végétale: Valeur et importance dans quelques marchés de la région du Littoral-Cameroun. J. Appl. Biosci. 40, 27152726.

Rashid, M.H., Fardous, Z., Chowdhury, M.A.Z., Alam, M.K., Bari, M.L., Moniruzzaman, M., Gan, S.H., 2016. Determination of heavy metals in the soils of tea plantations and in fresh and processed tea leaves: An evaluation of six digestion methods. Chem. Central J. 10, 7.

Rates, S.M.K., 2001. Plants as a source of drug. Toxicon. 39, 603-613.

Rehman, H., Ullah Khan, R.U., Ahmad, I., 2013. Population based study of heavy metals in medicinal plant Capparis decidua. Int. J. Pharm. Pharmaceut. Sci. 5(1), 108-113.

Shad, A.K., Lajbar, K., Iqbal, H., Khan, B.M., Naveed, A., 2008. Profile of heavy metals in selected medicinal plants. Pak. J. Weed Sci. Res. 14(1-2), 101-110.

Sium, M., Kareru, P., Keriko, J., Girmay, B., Medhanie, G., Debretsion, S., 2016. Profile of trace elements in selected medicinal plants used for the treatment of diabetes in Eritrea. Scient. World J. 2016. Article ID 2752836. 7p.

Tiwari, K.K., Singh, N.K., Patel, M.P., Tiwari, M.R., Rai, U.N., 2011. Metal contamination of soil and translocation in vegetables growing under industrial waste water irrigated agricultural field of Vadodara, Gujarat, India. Ecotoxicol. Environ. Saf. 74, 1670-1677.

Tshibangu, M.I., Nsahlai, V.I., Kiatoko, M.H., Hornick, J.L., 2014. Heavy metals concentration in Adenodolichos rhomboideus (O. Hoffm.) Harms, forage growing on mining tailings in south east of Democratic Republic of Congo: Influence of washing, $\mathrm{pH}$ and soil concentrations. Int. J. Curr. Res. Biosci. Plant Biol. 1(5), 16-27.

Uddin, A.H., Khalid, R.S., Abbas, S.A., 2012. Determination of heavy metal concentration of different traditional medicine formulations available at the east coast region of Malaysia. Afr. J. Pharm. Pharmacol. 6(20), 1487-1491.

Waston, D., 1993. Safety of Chemicals in Food, Chemical Contaminants. Wiley and Sons, New York. 255p.

Weldegebriel, Y., Chandravanshi, B.S., Wondimub, T.Y., 
2011. Concentration levels of metals in vegetables grown in soils irrigated with river water in Addis Ababa. Ethiopia. Ecotoxicol. Environ. Saf. 77, 57-63.

WHO, 1989. Evaluation of Certain Food Additives and Contaminants (Thirty-third report of the Joint FAO/WHO Expert Committee on Food Additives). WHO Technical Report Series, No. 776,

WHO, 1998. Quality Control Methods for Medicinal Plant Materials. World Health Organization, Geneva.
WHO, 2005. Quality Control Methods for Medicinal Plant Materials. World Health Organization, Geneva.

Yusufa, A.A., Arowolob, T.A., Bamgboseb, O., 2003. Cadmium, copper and nickel levels in vegetables from industrial and residential areas of Lagos City, Nigeria. Food Chem. Toxicol. 41, 375-378.

Ziarati, P., 2012. Determination of contaminants in some Iranian popular herbal medicines. J. Environ. Anal. Toxicol. 2(1), 1-3.

\section{How to cite this article:}

Maffo Maffo, N. L., Zapfack, L., Youmbi, E., Dibong, S. D., Ntsomboh-Ntsefong, G., Nanfack, A. D’E., 2016. Heavy metal concentrations in some common medicinal plants from different geographical locations in Douala, Cameroon. Int. J. Curr. Res. Biosci. Plant Biol. 3(12), 10-23. doi: http://dx.doi.org/10.20546/ijcrbp.2016.312.002 